\title{
Health Education Using Booklet and Diary Media on the Self-Efficacy of Housewives with Hypertension
}

\author{
Rasdiyanah"*, Wiwin Wiarsih ${ }^{2}$, Sukihananto ${ }^{3}$ \\ ${ }^{1}$ Department of Community and Family Nursing, Faculty of Medicine and Health Sciences, \\ Universitas Islam Negeri Alauddin, Makassar, Indonesia \\ ${ }^{2,3}$ Department of Community Nursing, Faculty of Nursing, Universitas Indonesia, Depok, Indonesia \\ *Corresponding Email: rasdiyanah.ners@uin-alauddin.ac.id
}

\section{ARTICLE INFO \\ HOW TO CITED: \\ Rasdiyanah, R., Wiarsih, W \& Sukihananto, S. (2020). Health Education Using Booklet and Diary Media on the Self- Efficacy of Housewives with Hypertension. Jurnal Pendi- dikan Keperawatan Indonesia 6(1), p. 14-25}

DOI:

10.17509/jpki.v6i1.23205

ARTICLE HISTORY:

Received

February 10, 2020

Revised

May 09, 2020

Accepted

May 10, 2020

Published

June 20, 2020

\section{ABSTRACT}

Health education is one of intervention strategies in nursing. Optimization in its implementation requires media support, health promotion media that can be used are booklet and diary. Booklet provides more information and diary records daily activities. This research aimed to identify the effect of health education using booklet and diary on the self-efficacy of housewives with hypertension in Depok. This quasi experimental research used pre-post design with control group. The sampling technique used non probability sampling with consecutive sampling method. The total of samples were 66 respondents. Data were collected using an Indonesian version of the High Blood Pressure - Self Care Profile and analyzed using descriptive statistics. The result of independent $t$ test showed significant effect in the mean of self-efficacy value after health education using booklet and diary ( $\mathrm{p}$ value $=0.002<0.05$ ). In conclusion, health education using booklet and diary media could increase the self-efficacy of housewives. This health education needs to be applied to clients with hypertension to increase self-efficacy in conducting selfmanagement.

Keywords: Health education, Self-efficacy, Housewives.

\section{ABSTRAK}

Pendidikan kesehatan merupakan salah satu strategi intervensi dalam keperawatan. Optimalisasi dalam pelaksanaannya memerlukan dukungan media, media promosi kesehatan yang dapat digunakan diantaranya adalah booklet dan diary. Booklet memuat lebih banyak informasi dan diary mencatat aktivitas sehari-hari. Tujuan penelitian ini adalah untuk mengidentifikasi pengaruh pendidikan kesehatan menggunakan booklet dan diary terhadap efikasi diri ibu rumah tangga dengan hipertensi di Kota Depok. Penelitian quasi eksperiment ini menggunakan pre-post design with control group. Teknik sampling menggunakan non probability sampling dengan metode consecutive sampling. Total sampel sebanyak 66 responden. Data dikumpulkan menggunakan versi Indonesia High Blood Pressure - Self Care Profile dan dianalisis menggunakan statistik deskriptif. Hasil Independent $t$ test menunjukkan pengaruh signifikan pada rata-rata nilai efikasi diri setelah pendidikan kesehatan menggunakan booklet dan diary ( $p$ value $=0,002<0,05$ ). Sebagai kesimpulan bahwa pendidikan kesehatan menggunakan booklet dan diary dapat meningkatkan efikasi diri ibu rumah tangga. Pendidikan kesehatan ini perlu diterapkan pada klien dengan hipertensi untuk meningkatkan keyakinan diri dalam melakukan manajemen diri.

Kata kunci: Pendidikan Kesehatan, Efikasi Diri, Ibu Rumah Tangga 


\section{INTRODUCTION}

Health problems that show an increasing trend over time are non-communicable diseases, one of these is hypertension (Kemenkes RI, 2012). The high mortality rate caused by hypertension occurs due to epidemiological transition, like socio-economic, environmental and lifestyle changes that do unhealthy behaviors (Khalesi, Sharma, Irwin, \& Sun, 2016). WHO (2013) reveals that cardiovascular disease contributes to 17 million deaths or almost one third of the total number of deaths per year, complications due to hypertension are 9.4 million deaths worldwide per year. Data publication from Kemenkes RI (2014), also shows that hypertension is the cause of about $45 \%$ of heart disease deaths and $51 \%$ of stroke deaths.

Baseline health research showed the prevalence of hypertension in Indonesia in the age $\geq 18$ was $26.5 \%$. The prevalence of hypertension in West Java was $29.4 \%$. Depok was one of the cities in West Java that experienced the increase of hypertension, it was of 19,275 to 34,244 (20132016), and Tugu urban village is one of the areas in Depok that had the highest hypertension prevalence in the age 15-64, it was of 2,372 in 2016 (Kemenkes RI, 2013). The Increased of prevalence indicates the need for more effective prevention and control of hypertension.

The prevention and control of hypertension since 2015 have become a government program through the Directorate of Control of NonCommunicable Diseases and published a Technical Guideline for Finding and Managing Hypertension Diseases in 2006 (Direktorat PPTM, 2006). Other efforts are made through the health promotion of CERDIK, GERMAS and Posbindu PTM program but have not been able to control the prevalence of hypertension (Kementerian Kesehatan RI, 2012).

One group that experiences the increase of hypertension is housewives. This was due to the large amount of housewives' responsibilities that could cause stress (Putri \& Sudhana, 2013), less physical activity and excessive calorie consumption (Barma \& Sil, 2013), regular consumption of fast food (Tamanna, 2016), and contraception pill (Pangaribuan, Dina, \& Lolong, 2015). In addition, social demographic factors, such as education, income, tension in marriage, pent-up anger had been linked to an increase of blood pressure (Fitriani, 2012). Therefore, efforts are needed to solve the problem.

Self-management showed its effectiveness in lifestyle changes that were needed (Alvarez, Greene, Hibbard, \& Overton, 2016). The increase of self-management could be achieved by selfefficacy (Astuti, 2016). Achieving self-efficacy required education or health education (Dodt et al., 2013). Health education could progress optimally depended on the use of media that primarily encouraged health behavior changes (Notoatmodjo, 2012).

Booklet was chosen as health education media because it was able to provide more and detailed information (Adawiyani, 2013). The effectiveness of booklet as health education media, could be supported by diary as a tool of recording the activities (Barak, Amoyal, \& Kalichman, 2013).

Several findings had proven the effectiveness of booklet as health education media. Research conducted by Ünsal and Kaşıcçı (2010) showed that interventions with booklet could increase the self-efficacy of respondents with arthritis, and respondents had the confidence to improve health status. Other research by Hemmati Maslakpak and Raiesi (2014) showed that interventions with booklet could improve the selfefficacy of multiple sclerosis patients in conducting self-management and follow-up programs. Last, research by Pichayapinyo, Kaewpan, and Taechaboonsermsak (2012) showed that interventions with booklet could increase the self-efficacy of participants with cardiovascular risk.

In addition to the use of booklet, diary was also used in health education. Ketelle (2012) reveals that diaries are intended to record the actions and habits experienced by individuals. Diary is designed to store various written information related to problems or daily activities 
carried out by individuals (Khoiriyyah \& Ediati, 2015). Diary also has aspects that encompass behavior, attitudes, values and feelings of the participants (Cucu-Oancea, 2013).

Diary was chosen for gathering important data. Moreover, diary provides more information than interview or observation (Woll, 2013). In addition, diary is also an important tool in research on stress, emotions, and health (Gunthert \& Wenze, 2014).

Several findings had proven the effectiveness of diaries as media for health education. Urzi, Stapleton, and Chatwin (2016) showed that diary as a recording tool that improved exercises and dietary patterns, and simultaneously increased self-efficacy. This happened because the diary worked as a recording tool that could increase self-efficacy. Furthermore, Weibull, Cumming, Cooley, Williams, and Burns (2015) in their research showed that Imagery diary was able to increase the self-efficacy of women with low physical activity, thus enabled the success of physical exercise adherence. Based on this, the researcher wanted to identify the effect of health education using booklet and diary on the selfefficacy of housewives with hypertension.

\section{METHODS}

\section{Population and sample}

The research employed quasi-experimental research using pre-post design with control group (Polit \& Beck, 2014). The population of research was housewives with hypertension in Depok. The sample of research was 66 respondents, consisted of 33 respondents for the intervention group and 33 respondents for the control group. The total of samples was obtained using the hypothesis test of two different means and gained 28 respondents for each group. Sastroasmoro and Ismael (2014) explain that the calculation of sample size in numerical analytical research on the mean of two paired populations can use the two different means formula.

The addition of sample numbers was conducted to anticipate dropped out samples by using a correction value of $10 \%$. Sastroasmoro and Ismael (2014) explain that the anticipation of samples that had dropped out was conducted by correcting or adding the number of samples through the correction formula of sample drop out. The results obtained 35 respondents for each intervention andn control group or the total sample was 70 respondents. However, until the end of research there were only 66 respondents with 33 respondents in the intervention and control group.

\section{Sampling technique}

The sampling technique was non probability sampling with consecutive sampling method (Sugiyono, 2011). The inclusion criteria in this research were housewives who were jobless, housewives who suffered hypertension $\geq 5$ years, housewives who did not have hearing impairment, were able to communicate verbally and speak Indonesia, were able to read and write. Exclusion criteria in this research were housewives who had movement disorders, housewives who were in pregnancy, housewives with complications of diseases such as diabetic ulcers, kidney failures and strokes. Drop out was conducted if respondent did not follow more than two sessions or more than one meeting (Sastroasmoro \& Ismael, 2014).

\section{Data collection instrument}

The instrument of research was HBP-SCP (High Blood Pressure - Self Care profile), HBPSCP is a questionnaire consists of 20 questions that assesses self-efficacy, clients with hypertension or respondents in conducting self-management related to hypertension (Han, Lee, CommodoreMensah, \& Kim, 2014). This instrument was given to respondents before the intervention (pre-test) and after the intervention (post-test). This instrument used Likert Scale with 4 scales, namely very confident (4), confident (3), less confident (2) and not confident (1) with the highest score 80 and lowest 20.

\section{Testing instrument}

The research instrument had been translated by experts and conducted a pilot study. The research instrument trial was conducted on 30 housewives with hypertension in Curug urban 
village, Depok. Curug urban village had similar characteristics with Tugu urban village where the research was carried out and both urban villages were still in one subdistrict, Cimanggis subdistrict, Depok. The instrument trials were conducted through direct visits, the researcher visited housewives who suffered from hypertension based on posbindu PTM data that had been carried out in Curug urban village.

\section{Instrument validity test}

The research validity test was face validity and content validity. Polit and Beck (2014) explain that face validity is an assessment of instrument form on conformity with research problem. Whereas, content validity is an instrument assessment based on the content of instrument used to determine the extent of the instruments describes the concepts that exist in research. The validity test of research instrument was carried out using the Pearson product moment (r) correlation test. The validity test results of research instrument showed the value ( $r$ count $)>(r$ table), where the $r$ count value for the self-efficacy instrument was in the range of $0.391-0.806$ and $r$ table was 0.361 . These results indicated the instrument was valid for the research.

\section{Instrument reliability test}

The reliability test of research instrument carried out using the Cronbach's Alpha method with a value of $r$ alpha> reliability value (0.8-1). These results indicated the research instrument was valid for the research. Cronbach's Alpha method is a method used to analyze the average of internal consistency of each question point (Dharma, 2011; Sugiono, 2014). The results of reliability test for self-efficacy instrument showed that $r$ Alpha Cronbach > reliability value $0.905>(0.8-1)$, it could be concluded that the self-efficacy instrument had a level of reliability to be used in research. In addition, this research also used booklet and diary as guidelines in implementing interventions. The media readability test in this research was conducted by nursing experts from the University of Indonesia (supervisor in this research).

\section{Time and place of research}

The research was conducted in Tugu urban village with a research period of May to June 2017 for one month with two weeks of intervention with a total meeting of eight sessions and two weeks of internalization. Before the intervention, the housewives with hypertension were given pre-test to assess their self-efficacy. The next meeting was to provide health education intervention. The intervention was carried out with a duration of two meetings each week, in each meeting two materials (two sessions) were presented. Moein, Aghajani, Ajorpaz, and Khorasanifar (2017) explain that health education intervention carried out in four meetings with two intervention sessions every week can effect on the self-efficacy of diabetic patients in conducting self-care.

\section{Data collection procedure}

The implementation of health education was carried out using face-to-face and demonstration with the aid of booklet. The booklet contained eight educational materials for clients with hypertension. The booklet materials consisted of hypertension concept and its treatment; stress management for clients with hypertension; hypertension medication and health control; physical exercise for clients with hypertension; obesity management, calculation of body mass index and abdominal circumference; nutrition management; Rest and sleep, effects of cigarettes and alcoholic drinks for health. The booklet was presented as educational media in the intervention and to be taken home, so that the housewives could repeat and practice booklet materials at home.

In addition to the booklet, housewives were also given diary to monitor daily activities, especially the implementation of nursing interventions that had been provided through faceto-face health education. The diary consisted of nutrition monitoring, medication adherence, physical exercise, health control, BMI monitoring, sheets for housewives to write things that made them angry and how housewives deal with anger, and tables of normal blood pressure values, ideal body weight, normal values of cholesterol, uric 
acid, and blood sugar. Housewives were given instructions to fill in the diary as a way to get them accustomed to managing hypertension that could encourage housewives self-efficacy. The filling of diary was carried out every day for one month and was controlled in each session of the health education meeting. Kristjánsdóttir et al., (2013) explains the implementation of 4 weeks diary can build self-management, support patient awareness, and reflect on experiences related to pain, feeling and activities.

After two weeks of health education, continued with an internalization period in the intervention group in order to see changes in selfefficacy of housewives with hypertension for two weeks. After the internalization period, a post-test was conducted to assess changes in self-efficacy of housewives with hypertension. Post test was not conducted when the intervention completed, however, it was conducted two weeks after the intervention or after the internalization period had finished. This was intended to provide housewives time to familiarize themselves with hypertension management as taught during health education and to reduce bias during research.

In the control group pre-test was conducted related to the self-efficacy of housewives in self managing hypertension and provided direct faceto-face health education in two meetings related to the hypertension management materials in the booklet. After one month, post-test was conducted to assess housewives self-efficacy in the control group. After the post test had been conducted, the control group was provided booklet and diary as education and monitoring material at home to further enhance their abilities and encouraged selfefficacy in managing hypertension.

\section{Data analysis}

\section{Univariate analysis}

The Univariate data analysis was carried out to describe the characteristics of respondents and to assess the normality and homogeneity of two groups. Data normality test used the skewness method, with the data criteria were at the skewness ratio value of -2 to 2 . The normality test was performed on numerical data type variables, namely age and self-efficacy with the normality test values of $-0,290$ and $-0,246$ or were at the skewness ratio value -2 to 2 . These results indicated that the age and self-efficacy variables were normally distributed, so that they were presented using mean and standard deviation.

In addition, the homogeneity of research variables was tested between the two groups as a condition of the Univariate test. Homogeneity test for categorical variables was carried out using the chi-square test with the alternative fisher exact test. The results showed the $\mathrm{p}$ value for the variable of education level (0.172), educational status (0.708), socio-economic status (1.0) and health complaints (1.0)> 0.05 , so it could be concluded that these variables had the same variances between groups intervention and control or homogeneous. Homogeneity test for variables with numerical data, namely age and self-efficacy was carried out with the Levene's test. The results showed age $p$ value $(0.220)$ and self-efficacy $(0.237)>0.05$, so it could be concluded that the age and self-efficacy variables also had the same variances between the intervention and control or homogeneous groups.

\section{Bivariate analysis}

The Bivariate data analysis in this research was carried out to see the effect of health education using booklet and diary on the self-efficacy of housewives with hypertension. Bivariate analysis was performed using parametric analysis with statistical tests, paired $t$ test and pooled t test. The test was conducted to present the normally distributed variables with the condition of groups' variants that had homogeneous data. Bivariate analysis resulted if the $p$ value $<0.05$.

\section{Research ethics}

Research had also been declared to have passed the ethical test of FIK UI 2017 No. 136/UN2.F12.D/HKP.02.04/2017, and during the research there was nothing that harmed housewives physically or psychologically. Polit and Beck (2014) explain that a researcher must meet ethical principles consisting of benefit, respect for human dignity, and justice. 
Rasdiyanah, R., Wiarsih, W \& Sukihananto, S.| Health Education Using Booklet and Diary Media on the Self-Efficacy ...

\section{RESULT}

Table 1 shows that the average age of respondents in the intervention group was 46.18 and the control group was 46.27. Respondents in both groups were still in the productive age category.

Table 1. The Distribution of Characteristics of Respondents by Age in Tugu urban village, $\operatorname{Depok}(n=66)$

\begin{tabular}{cccc}
\hline Variable & Group $(\mathbf{n}=\mathbf{6 6})$ & Mean & SD \\
\hline \multirow{2}{*}{ Age } & Intervention & 46,18 & 8,191 \\
\cline { 2 - 4 } & Control & 46,27 & 7,195 \\
\hline
\end{tabular}

Table 2 shows that the education level of respondents was mainly on elementary school, it was of $72.8 \%$ for the control group and $45.5 \%$ for the intervention group. Based on marital status, respondents were married for the control group $90.9 \%$ and for the intervention group $84.8 \%$. Based on income, both groups had lower minimum incomes (<UMK) $84.8 \%$ for control group and $81.8 \%$ for intervention group. Based on health complaints from both groups, they were respectively of $87.9 \%$.

Table 2. The Distribution of Characteristics Based on Education Level, Marital Status, Income and Complaints of Respondents in Tugu urban village, Depok $(n=66)$

\begin{tabular}{|c|c|c|c|c|}
\hline \multirow{3}{*}{$\begin{array}{c}\text { Housewives } \\
\text { Characteristics }\end{array}$} & \multicolumn{4}{|c|}{ Group } \\
\hline & \multicolumn{2}{|c|}{$\begin{array}{c}\text { Intervention } \\
(\mathbf{n}=\mathbf{3 3})\end{array}$} & \multicolumn{2}{|c|}{$\begin{array}{c}\text { Control } \\
(\mathbf{n}=33)\end{array}$} \\
\hline & (n) & $(\%)$ & (n) & $(\%)$ \\
\hline \multicolumn{5}{|c|}{ Education Level } \\
\hline 1. University/ College & 4 & 12,1 & - & 0 \\
\hline $\begin{array}{l}\text { 2. } \begin{array}{l}\text { Senior high school/ } \\
\text { equivalent) }\end{array} \\
\end{array}$ & 14 & 42,4 & 9 & 27.3 \\
\hline $\begin{array}{ll}\text { 3. } & \text { elementary (no } \\
\text { education, elementary } \\
\text { school, Junior high } \\
\text { school) }\end{array}$ & 15 & 45,5 & 24 & 72,8 \\
\hline \multicolumn{5}{|c|}{ Marital status } \\
\hline 1. Married & 28 & 84,8 & 30 & 90,9 \\
\hline 2. Widowed & 5 & 15,2 & 3 & 9,1 \\
\hline \multicolumn{5}{|c|}{ Income } \\
\hline 1. $\quad<3.297 .489$ & 27 & 81,8 & 28 & 84,8 \\
\hline 2. $\geq 3.297 .489$ & 6 & 18,2 & 5 & 15,2 \\
\hline \multicolumn{5}{|c|}{ Health Complaint } \\
\hline 1. No & 4 & 12,1 & 4 & 12,1 \\
\hline 2. Yes & 29 & 87,9 & 29 & 87,9 \\
\hline
\end{tabular}

Table 3 shows that the self-efficacy of respondents in both groups was almost same, but the mean of self-efficacy from control group was 54.55 , which was higher than in the intervention group, namely 50.45. After conducting intervention, the self-efficacy of intervention group had increased with the mean value of 59.91 and the control group had decreased with the mean value of 54.15. These results indicated the increase of self-efficacy value before and after intervention, the mean value difference of 9.46 in the intervention group.

Table 3. The Distribution of Mean Value of Self-Efficacy Before and After Health Education on Intervention and Control Groups in Tugu urban village, Depok $(n=66)$

\begin{tabular}{lccc}
\hline Self-Efficacy & $\begin{array}{c}\text { Group } \\
(\mathbf{n}=\mathbf{6 6})\end{array}$ & Mean & SD \\
\hline \multirow{2}{*}{ Before } & Intervention & 50,45 & 5,901 \\
\cline { 2 - 4 } & Control & 54,55 & 7,637 \\
\hline \multirow{2}{*}{ After } & Intervention & 59,91 & 7,299 \\
\cline { 2 - 4 } & Control & 54,15 & 7,009 \\
\hline
\end{tabular}

Table 4 shows that the result of paired $t$ test in the intervention group with the mean difference of 9.46 and $p 0,000<0.05$, it indicated that there were differences in self-efficacy before and after the intervention. Whereas, in the control group, the result showed the mean difference of -0.4 and $\mathrm{p}$ $0.287>0.05$, it indicated that was no difference in the value of self-efficacy before and after the intervention. The mean different values showed the decrease of self-efficacy in the control group after getting health education. Based on the results, it could be concluded that the self-efficacy value of the intervention group was higher than the control group.

Table 4. The Analysis of Differences on the Effect of Housewives Self-Efficacy between Intervention and Control Groups in Tugu urban village, Depok $(n=66)$

\begin{tabular}{|c|c|c|c|c|c|}
\hline \multirow[t]{2}{*}{ Variable } & \multicolumn{2}{|c|}{$\begin{array}{l}\text { Intervention } \\
\text { Group }\end{array}$} & \multicolumn{2}{|c|}{$\begin{array}{l}\text { Control } \\
\text { Group }\end{array}$} & \multirow[t]{2}{*}{$p$} \\
\hline & Mean & SD & Mean & SD & \\
\hline Self-efficacy & 59,91 & 7,299 & 54,15 & 7,009 & 0,002 \\
\hline
\end{tabular}




\section{DISCUSSION}

The self-efficacy of both groups before health education was almost same. In table 3, the self-efficacy of control group before the intervention was in the mean value of 54.55 while the self-efficacy of intervention group before the intervention was in the mean value of 50.45. The differences in the value of self-efficacy in the control group before intervention, were influenced by the level of age maturity in the control group which was bigger with the mean of 46.27 than the intervention group with the mean of 46.18. Potter, Perry, Stockert, Hall and Peterson (2013) implies that person in age 40-60 or in the middle adult age has good self-sefficacy because in that age a person has a level of maturity of thinking, so that he/she is able to judge and guide him/herself. This was consistent with the theory of Bandura, (2016) which explains that the adulthood for entities is to grasp the higher standard, as well as to get selfjustifications that supports them.

The value of housewives self-efficacy in the control group based on respondents' characteristics data was also influenced by the marital status of respondents. The results of the analysis showed that housewives who were married in the control group were bigger with the mean of 90.9 than housewives in the intervention group with the mean of 84.8. Research conducted by Pratita (2012) and Al-Kahfi, Palimbo and Marlina (2016) found that partner support and self-efficacy of DM patients had a significant correlation to the adherence of undergoing treatment. Moreover, Wahyuni and Rezkiki (2015) also found that the existence of a spouse was a form of support that could affect selfefficacy, thus increased the client's health status. Wahyuni, Nurrachmah and Gayatri, (2012) also explained that the intimacy or support of a spouse had an important role in the recovery of cardiovascular disease. This was in line with Bandura, Caprara, Barbaranelli, Regalia and Scabini (2011) that the efficacy of spousal relationship is one part of the reliant family structures. Spousal efficacy focuses on the complexities in their relationship that changes the nature of family function and fulfillment of family existences.
After conducting the intervention, there was a change in the value of self-efficacy in the intervention group. The value of self-efficacy in the intervention group had increased, whereas in the control group the value of self-efficacy had decreased slightly. The mean value of housewives self-efficacy had increased to 59.91, while in the control group the mean value of self-efficacy had decreased to 54.15. The changes in the value of self-efficacy in the intervention group caused by the level of housewives education level, in this research, the education level was almost balanced between elementary and higher education levels, in the intervention group there was $12.1 \%$ who had achieved university, while in the control group there was no respondent who had university level. This was consistent with the theory of Bandura (2016) which emphasizes that the acquirement of information, skill, and acceptance of efficacy through education empower women to control over their lives. The statement indicated that the intervention group captured information more quickly because most of the educational background was in the higher level.

Other factors were the changes of selfefficacy before and after the intervention, Bandura (2015) explains that Perceived self-efficacy functions as a self-control of motivation and action through planned objectives. The more individuals consider about their abilities, the higher of complexities arranged for themselves and the more intense of their responsibilities. In this research, respondents were given health information about controlling blood pressure or living in a healthy lifestyle based on physical and emotional conditions, thus it encouraged the self-efficacy of housewives.

Bonsaksen, Lerdal and Fagermoen (2012), in their research explained that self-efficacy of clients suffered from chronic disease was influenced by internal and external factors that existed on the clients. Internal factors came from within the clients that could affect their beliefs, such as the emotional response of clients to their illnesses, while external factors could come from the presence of a good support system that came 
from the family and social environment. The intervention in this research was a support system that came from external support or social environment so that it could improve selfefficacy.

The results of this research were consistent with the research conducted by Wayunah, Saefulloh and Nuraeni (2016) which showed the self-efficacy of the intervention group after being given structured education had increased, the mean before the intervention was of 70.14 and after the intervention had changed to 80.14 (an increase of 10 points) with a value of $\mathrm{p}=0,000$, so that it could be concluded that the education could increase the client's self-efficacy.

The Increase of housewives self-efficacy after an intervention in the form of health education, caused by the formed efficacy process. In addition, Bandura (2015) emphasizes four processes of the formation of efficacy, namely cognitive processes, motivational processes, affective processes and selection processes. These processes played roles when health education was given, Wayunah, Saefulloh and Nuraeni (2016) explain one of the efficacy processes that are formed when health education is given is a cognitive process, this process could encourage or prevent housewives in forming changes in behavior. That was because during the implementation of health education there was a continuous process of providing information and knowledge related to health problems experienced by housewives, so the more often the positive information was conveyed, the bigger the selfefficacy was formed.

Other research on self-efficacy was also carried out by Daniali, Shahnaz, Kazemi and Marzbani (2016), From the result of the research it was found that the self-efficacy value of multiple sclerosis patients at the pretest for the intervention and control groups was in the low category. After the intervention was carried out in the form of providing health education about pain management, the self-efficacy values of the intervention group had increased or were in the high category, with a mean pretest value of 47.77 and a mean posttest value of 69.40 (an increase of 21.63).

This was also related to the research conducted by Rachmawati, Ranuh and Arief (2016), which explained the things that could strengthen someone's self-efficacy came from the experiences of others who had the same problems. During the health education, respondents in the intervention group were more enthusiastic and more communicative in sharing their experiences dealt with increased blood pressure and symptoms perceived. This could form self-efficacy through affective processes, namely positive emotional development that was related to attitudes, values in responding, accepting and combining many values hold by each individual, so that it could influence behavior.

Based on table 4 above, it was clear that the provision of health education using booklet and diary could increase respondents' self-efficacy. Nies, Mcewen, Cassells and Miskovich (2011) explain that health education can be in the form of media. Media as a learning facility serves to bring out the interest of educational objects, achieve educational goals, provide stimulus on educational objects, in order to continue received messages to other objects, support the understanding, facilitate the conveyance and reception of information or messages (Notoatmodjo, 2012). These results indicated the effectiveness of booklet and diary in increasing someone's self-efficacy. The results of this research were consistent with research conducted by (Ünsal \& Kaşıkç1, 2010), the research provided health education through booklet to respondents with arthritis, the research indicated the increase of self-efficacy in the experimental group.

Booklet is a print media for health promotion. The use of print media, booklet, was considered to be more effective in providing more health information, so that the information conveyed could be received by individuals, families or communities. In addition, the knowledge acquired by someone comes from visuals, while the rest is acquired through other senses (Notoatmodjo, 2012). In addition, 
Machfoedz and Suryani (2013), also state that the booklet has the purposes of delivering promotions, suggestions, restrictions in the form of print media.

Related to above, the research conducted by Pichayapinyo et al. (2012) toward respondents with the risk of cardiovascular diseases showed the increase of self-efficacy of respondents, the effect of personal health record booklet (PHRB) had effectively increased the self-efficacy of respondents with the risk of cardiovascular diseases. Booklets could keep the self-efficacy of respondents regarded to be the steps in carrying out daily activities, the existence of information and recommendations related to healthy behaviors and illustrations could encourage the increase of selfefficacy of respondents. Related to this, Mardhiah, Abdullah, Hermansyah (2016), in their research showed that the health education provided to hypertensive patients using booklet could improve the patient understanding on the conveyed messages.

In addition to the use of booklet, this research was also supported by the use of diary as a recording tool to increase housewives selfefficacy in conducting self-management related to hypertension and healthy lifestyles. The research of Weibull et al., (2015) provided health education on women with imagery diary. Regarding women'

\section{REFERENCES}

Adawiyani R. (2013). Jurnal Ilmiah Mahasiswa Universitas Surabaya. Jurnal Ilmiah Mahasiswa Universitas Surabaya, 2(2), 1 20-21 - 20. Retrieved from http://www.journal.ubaya.ac.id/index.php/ji mus/article/view/725

Alvarez, C., Greene, J., Hibbard, J., \& Overton, V. (2016). The role of primary care providers in patient activation and engagement in selfmanagement: A cross-sectional analysis. BMC Health Services Research, 16(1), 1-8. https://doi.org/10.1186/s12913-016-1328-3

Astuti, N. (2016). Efikasi Diri Dan Manajemen Diri Pada Pasien Diabetes Tipe 2, 5(1), 13-18. Retrieved from http://repository.usu.ac.id/handle/123456789/ 44550 self-efficacy, there was an increase of self-efficacy after health education was given. Health education through imagery diary could increase the selfefficacy of women with low physical activity.

Another research by Urzi et al. (2016) showed that the use of diary as a recording tool simultaneously improved respondents' selfefficacy of exercise and dietary patterns. This happened, because the use of diary in health education could increase respondents' selfawareness. This research showed the effectiveness of diary in recording the changes of activities or behaviors of respondents in conducting selfmanagement.

\section{CONCLUSION}

The results showed that the health education using booklet and diary could support housewives to increase self-efficacy on self-management as an effort to manage hypertension.

\section{ACKNOWLEDGEMENT}

This research would not have been possible without the support of all the research team and all the participants, the authors wish to appreciate Hae-Ra Han, RN, PhD, FAAN for her great help in permitting HBP-SCP (High Blood Pressure - Self Care Profile) instrument to be used in this research.

Bandura, A. (2015). Cultivate Self-efficacy for Personal and Organizational Effectiveness. (E. A. Locke, Ed.), Handbook of Principles of Organizational Behavior (First). West Sussex: John Wiley \& Sons, Ltd. https://doi.org/10.1002/9781119206422.ch6

Bandura, A. (2016). Moral Disengagement (First). New York Plaza: Worth Publishers.

Bandura, A., Caprara, G. V., Barbaranelli, C., Regalia, C., \& Scabini, E. (2011). Impact of family efficacy beliefs on quality of family functioning and satisfaction with family life. Applied Psychology, 60(3), 421-448. https://doi.org/10.1111/j.14640597.2010.00442.X

Barak, F., Amoyal, M., \& Kalichman, L. (2013). Using a simple diary for management of nausea and vomiting during chemotherapy. 
Clinical Journal of Oncology Nursing, 17(5), 479-481.

https://doi.org/10.1188/13.CJON.479-481

Barma, R. S., \& Sil, P. (2013). A comparative study of health and nutritional status among housewives and working women of north bengal 1. International Journal of Behavioral Social and Movement Sciences, 02(04), 3540.

Bonsaksen, T., Lerdal, A., \& Fagermoen, M. S. (2012). Factors associated with self-efficacy in persons with chronic illness. Scandinavian Journal of Psychology, 53(4), 333-339. https://doi.org/10.1111/j.14679450.2012.00959.x

Cucu-Oancea, O. (2013). Using Diaries - A Real Challenge for the Social Scientist. Procedia Social and Behavioral Sciences, 92(Lumen), 231-238.

https://doi.org/10.1016/j.sbspro.2013.08.665

Daniali, S., Shahnaz, H., Kazemi, S., \& Marzbani, E. (2016). The Effect of Educational Intervention on Knowledge and Self-efficacy for Pain Control in Patients with Multiple Sclerosis. Materia Socio Medica, 28(4), 283. https://doi.org/10.5455/msm.2016.28.283287

Direktorat PPTM, D. P. \& P. (2006). Pedoman Teknis Penemuan dan Tatalaksana Penyakit Hipertensi.

Jakar. https://doi.org/10.1017/CBO9781107415324. 004

Dodt, R. C. M., Ferreira, Á. M. V., do Nascimento, L. A., Macêdo, A. C., Joventino, E. S., \& Ximenes, L. B. (2013). Influence of health education strategy mediated by a self-efficacy breastfeeding serial album. Texto e Contexto Enfermagem, 22(3), 610-618. https://doi.org/10.1590/S010407072013000300006

Fitriani, A. (2012). Kondisi Sosial Ekonomi dan Stres pada Wanita Hipertensi Anggota Majelis Taklim. Kesmas: National Public Health Journal, 7(5), 214. https://doi.org/10.21109/kesmas.v7i5.43

Gunthert, Kathleen C, Susan J, wenze. (2014). Daily Diary Methods. In C. Mehl, Matthias R; Tamlin S (Ed.), Handbook of Research Methods for Studying Daily Life (pp. 1-706). New York: The Guilford Press.
Han, H. R., Lee, H., Commodore-Mensah, Y., \& Kim, M. (2014). Development and validation of the hypertension self-care profile: A practical tool to measure hypertension selfcare. Journal of Cardiovascular Nursing, 29(3), $1-16$. https://doi.org/10.1097/JCN.0b013e3182a3fd 46

Hemmati Maslakpak, M., \& Raiesi, Z. (2014). Effect of a Self-Management and Follow-Up Program on Self-Efficacy in Patients With Multiple Sclerosis: A Randomized Clinical Trial. Nursing and Midwifery Studies, 3(4). https://doi.org/10.17795/nmsjournal25661

Ircham Machfoedz; Eko Suryani. (2013). Pendidikan Kesehatan Bagian dari Promosi Kesehatan (9th ed.). Yogyakarta: Fitramaya.

Kemenkes RI. (2012). buletin-ptm.pdf. Jakarta.

Kemenkes RI. (2013). Riset Kesehatan Dasar. Kementrian Kesehatan RI, (1), 1-303. https://doi.org/10.1007/s13398-014-0173-7.2

Kemenkes RI. (2014). Situasi Kesehatan Jantung. Pusat Data Dan Informasi Kementerian Kesehatan RI, 1-8. https://doi.org/10.1017/CBO9781107415324. 004

Kementerian Kesehatan RI. (2012). Petunjuk Teknis Pos Pembinaan Terpadu Penyakit Tidak Menular (Posbindu PTM). Ditjen Pengendalian Penyakit Dan Penyehatan Lingkungan, Kementerian Kesehatan RI, 1$39 . \quad$ Retrieved from http://p2ptm.kemkes.go.id/uploads/2016/10/ Petunjuk-Teknis-Pos-Pembinaan-TerpaduPenyakit-Tidak-Menular-POSBINDU-PTM2013.pdf

Ketelle, D. (2012). Talking to Myself : Diary as a Record of Life Process Mills College. International Journal of Humanities and Social Science, 2(7), 34-40.

Khalesi, S., Sharma, S., Irwin, C., \& Sun, J. (2016). Dietary patterns, nutrition knowledge and lifestyle: Associations with blood pressure in a sample of Australian adults (the Food BP study). Journal of Human Hypertension, 30(10), 581-590. https://doi.org/10.1038/jhh.2016.22

Khoiriyyah, A., \& Ediati, A. (2015). Pengaruh Buku Harian untuk Meningkatkan Kepatuhan Pada Pasien Hipertensi: Studi Kuasi 
Eksperimen pada Pasien Hipertensi. Empati, 4(1), 35-42.

Kristjánsdóttir, Ó. B., Fors, E. A., Eide, E., Finset, A., Stensrud, T. L., Van Dulmen, S., ... Eide, H. (2013). A smartphone-based intervention with diaries and therapist feedback to reduce catastrophizing and increase functioning in women with chronic widespread pain. part 2: 11-Month follow-up results of a randomized trial. Journal of Medical Internet Research, 15(3), 1-19. https://doi.org/10.2196/jmir. 2442

Kusuma Kelana, D. (2011). Panduan Panduan Melaksanakan dan Menerapkan Hasil Penelitian. Metodologi Penelitian Keperawatan.

Mardhiah, Ainal;Abdullah, A. H. (2016). Pendidikan Kesehatan Dalam Peningkatan Pengetahuan, Sikap Dan Keterampilan Keluarga Dengan Hipertensi - Pilot Study. Jurnal Ilmu Keperawatan, 3(2).

Moein, M., Aghajani, M., Ajorpaz, N. M., \& Khorasanifar, L. (2017). Effect of an empowerment program on self-efficacy of patients with type 2 diabetes. Iranian Red Crescent Medical Journal, 19(1), 1-7. https://doi.org/10.5812/ircmj.29252

Nies, M. A., Mcewen, M., Cassells, H., \& Miskovich, L. M. (2011). Community / Public Health Nursing: Promoting the Health of Populations 5th Edition Chapter 5 Epidemiology.

Notoatmodjo, S. (2012). Promosi Kesehatan dan Perilaku Kesehatan (Edisi Revisi: 2010). Jakarta, Indonesia: Rineka Cipta.

P.D, S. (2014). Metode penelitian pendidikan pendekatan kuantitatif.pdf. Metode Penelitian Pendidikan Pendekatan Kuantitatif, Kualitatif Dan $R \& D$.

Pangaribuan, L., \& Lolong, D. B. (2015). Hubungan penggunaan kontrasepsi pil dengan kejadian hipertensi pada wanita usia 15-49 tahun di Indonesia tahun 2013 (analisis data riskesdas 2013). Media Penelitian dan Pengembangan Kesehatan, 25(2), 89-96.

Pichayapinyo, P., Kaewpan, W., \& Taechaboonsermsak, P. (2012). Effect of personal health record booklet (PHRB) to knowledge, self-efficacy and healthy behaviors among Thai population at risk of cardiovascular disease (CVD). Journal of the Medical Association of Thailand, 95(SUPPL 6), 48-55.

polit, Denise F \& Beck, C. T. (2014). Essentials of Nursing Research Appraising Evidence for Nursing Practice (8th ed.). St. Philadelphia: Lippincott Williams \& Wilkins.

Potter, P. A., Perry, A. G., Stockert, P., Hall, A., \& Peterson, V. (2013). Clinical Companion for Fundamentals of Nursing.

Pratita, N. D. (2012). Hubungan Dukungan Pasangan dan Health Locus of Control dengan Kepatuhan dalam menjalani Proses Pengobatan pada Penderita Diabetes Mellitus Tipe 2. Jurnal Ilmiah Mahasiswa Universitas Surabaya, 1(1), 24. Retrieved from https:// journal.ubaya.ac.id/index.php/jimus/article/vi ew/56

Putri, K. A. K., \& Sudhana, H. (2013). Perbedaan Tingkat Stres Pada Ibu Rumah Tangga yang Menggunakan dan Tidak Menggunakan Pembantu Rumah Tangga. Jurnal Psikologi Udayana, 1(1), 94-105.

Rachmawati, P. D., Ranuh, R., \& Arief, Y. (2016). Model Pengembangan Perilaku Ibu Dalam Pemenuhan Kebutuhan Asah, Asih Dan Asuh Anak Leukemia. Jurnal NERS, 11(1), 63. https://doi.org/10.20473/jn.v11i12016.63-72

Rina Al-Kahfi; Adriana Palimbo; Marlina. (2016). Pengaruh Efikasi Diri Dan Dukungan Keluarga terhadap Pencegahan Kaki Diabetik Pada Pasien Rawat Jalan Diabetes Mellitus Tipe 2 Di RSUD Dr. H. Moch. Ansari Saleh Banjarmasin. Dinamika Kesehatan, 7(2), 332-346.

Sastroasmoro, S., \& Ismael, S. (2014). DasarDasar Metodologi Klinis Edisi Ke-4. In Dasar-Dasar Metodologi Peneltian Klinis. https://doi.org/10.15294/UJPH.V2I1.3034

Sugiyono. (2011). Metode Penelitian Kombinasi (Mixed Methods). Bandung: Alfabeta. https:// doi.org/10.1016/S0969-4765(04)00066-9

Tamanna, M. K. (2016). Consumers 'Interest in Fast Food Items- A Study on Sylhet City of Bangladesh. The International Journal of Business \& Management, 4(3), 315-320.

Ünsal, A., \& Kaşıkçı, M. K. (2010). Effect of Education on Perceived Self-Efficacy for Individuals with Arthritis. International Journal of Caring Sciences, 3(1), 3-11. 
Urzi, D., Stapleton, P., \& Chatwin, H. (2016). The use of a daily diary system to promote selfmonitoring and improve health-related identity and self-efficacy. Graduate Journal of Sport, Exercise \& Physical Education Research, 4, 14-28. Retrieved from http://epublications.bond.edu.au/cgi/viewcon tent.cgi?article $=1527 \&$ context=fsd_papers

Wahyuni, A., Nurrachmah, E., \& Gayatri, D. (2012). Kesiapan pulang Pasien Penyakit Jantung Koroner Melalui Penerapan Discharge Planning. Jurnal Keperawatan Indonesia, 15(3), 151-158. https://doi.org/10.7454/jki.v15i3.3

Wahyuni, A., \& Rezkiki, F. (2015). Pemberdayaan dan Efikasi Diri Pasien Penyakit Jantung Koroner melalui Edukasi Kesehatan Terstruktur. Jurnal Ipteks Terapan, 9(1), 2839. https://doi.org/10.22216/jit.2015.v9i1.26
Wayunah, Saefulloh, M., \& Nuraeni, W. (2016). Efficacy dan Menurunkan IDWG Pasien Hemodialisa. Pendidikan Keperawatan Indonesia, 2(1), 22-28.

Weibull, F., Cumming, J., Cooley, S. J., Williams, S. E., \& Burns, V. E. (2015). Walk this Way: A Brief Exercise Imagery Intervention Increases Barrier Self-Efficacy in Women. Current Psychology, 34(2), 477-490. https://doi.org/10.1007/s12144-014-9271-0

WHO. (2013). A global brief on hypertension $\mid A$ global brief on Hyper tension. Geneva. Retrieved from https://apps.who.int/iris/ handle/10665/79059

Woll, H. (2013). Process Diary as Methodological Approach in Longitudinal Phenomenological Research. Indo-Pacific Journal of Phenomenology, 13(2), 1-2. https://doi.org/ 10.2989/ipjp.2013.13.2.2.1176 